\title{
The Myth of Protagoras: A Naturalist Interpretation
}

\author{
Refik Güremen \\ Mimar Sinan University (MSGsü) - Istanbul, Turkey \\ refik2007@gmail.com
}

\begin{abstract}
Protagoras' Grand Speech is traditionally considered to articulate a contractualist approach to political existence and morality. There is, however, a newly emerging line of interpretation among scholars, which explores a naturalist layer in Protagoras' ethical and political thought. This article aims to make a contribution to this new way of reading Protagoras' speech, by discussing one of its most elaborate versions.
\end{abstract}

\section{Keywords}

Protagoras - morality - naturalism - contractualism - myth - justice - human nature

\section{Introduction}

The myth told by Protagoras in Plato's eponymous dialogue is traditionally read as intimating a contract theory of political and moral life. According to this contractualist reading, Protagoras assumes that political life begins with the establishment of certain norms for social behavior. Both the political life, and the ethical standards that ground it, are hence the products of a communal enterprise. In this reading, the gifts of Zeus represent a turn from a prepolitical life to a life in poleis.

Michel Narcy (1990 and 2008) provides a thoroughly contractualist interpretation of Protagoras' position. Narcy takes very straightforwardly Protagoras' announcement, at $320 \mathrm{c}$, of equivalence between the myth and the logos laid out in the second part of his Grand Speech. According to Narcy, Protagoras' logos contains nothing that was not already stated (allegorically) in the myth. Consequently, Narcy claims, the prose equivalent of the mythical Zeus is nothing other than the polis as a social organism. That is, the order established by 
Zeus' command to Hermes corresponds to the polis, and the universal endowment of human beings with 'shame and a sense of right' is equivalent to what a polis provides for its citizens. It corresponds to the universal care given by society to the moral education of its members, from children to the highest magistrates. Accordingly, the joint aim of the Protagorean myth and the logos would be to prove a "social essence" for morality. For Narcy, Protagoras reduces morality to "civility" in two reciprocal ways: not only does the polis prescribe moral norms for its members and endow them with moral notions to render them moral agents; but also it is the following of these norms that makes a polis. ${ }^{1}$ Moreover, Narcy thinks that for Protagoras, language is the only art available for our education in morality. It is this art, which can only be taught by society, that makes us moral beings, and education in virtue is thus nothing but 'saying' right from wrong. The art of speaking is therefore the political and moral art par excellence. ${ }^{2}$

One serious problem with such a contractualist approach is its circularity. According to this line of interpretation, it is moral education, on the one hand, which makes the poleis possible, but on the other hand, such an education can be secured only by the poleis.

A Recent Naturalist Reading of the Myth

Recently, an alternative naturalistic interpretation of Protagoras' myth has emerged. This approach remains underdeveloped and has not yet gained wide acceptance among scholars. ${ }^{3}$ A recent article by Adam Beresford (2013), however, provides a highly elaborate version of this nascent naturalistic reading. ${ }^{4}$ According to Beresford, Protagoras views morality as a part of human nature,

1 See especially Narcy (1990, p. 44).

2 Narcy (1990, pp. 44-45).

3 See Nussbaum (2001, p. 102-103), Vegetti (2004) and Bonazzi (2012). See also Van Riel (2012) on the naturalness of religion according to the myth.

4 In contemporary philosophy, the term "ethical naturalism" is used to designate a doctrine about the status of moral properties and facts, namely, the doctrine that there are moral properties and facts which are natural. However, here I use it to label the idea which refers the origins of morality and ethical behaviour to human nature. I use it in this sense because Beresford seems to do so. Although this use of the term is somewhat alien to its contemporary usage, I think it is correct in the present context since it corresponds fairly well to the question at stake in the ancient nomos/physis debate, which is the question of the origins and legitimacy of moral and political norms. 
and Zeus' gifts stand for a natural endowment: Zeus' command to Hermes allegorically represents the fact that ethical dispositions are not products of nomos, but rather belong to our nature at the most basic level. They are the foundations upon which we subsequently construct our education in virtue. When Protagoras affirms that ethical virtues do not arise in us by nature (323c5), all by themselves, he would thereby not mean that they have no basis in our nature. On the contrary, human nature, according to Protagoras, would have an 'unreflective grasp of the basic moral facts' and 'innate normative tendencies of the right kind'. These innate dispositions would be doing a major part of the work upon which moral education depends. Moral education is simply a 'blunt' instrument which 'triggers' our potential for morally right behavior. In Protagoras' account, it is hence not culture but nature that makes us moral beings; culture merely triggers our moral nature to be what it already potentially is.

Beresford thinks that this interpretation adequately captures the meaning of the myth because it is consistent with the general principle of the allegory of 'divine gifts'. There is a parallel between Zeus' gifts and Epimetheus' endowment of other animals with certain traits, insofar as both aim at promoting the survival of the living beings in question. The mythical notion of divine gifts generally functions according to this principle. Such gifts represent features of animal nature that prevent the extinction of the animal kind. As the story goes, Zeus also intervenes to promote the survival of human beings and hence gives us the gifts of dikê and aidôs. According to the general rationale of divine gifts in the myth, Zeus' gifts would stand for a normative instinct for the right kind of behavior, and morality would be a tool for human survival. Beresford concludes that 'we should see in the story an outline of the idea that our inclination towards fairness is a natural endowment, a characteristic of species $[\ldots]$ What Protagoras means, on this reading, [...] is not that we ever figured out its value ourselves, or "internalized" it by some essentially cultural process. In the same way, a bear's sharp and powerful teeth came into being because they enabled it to perpetuate its kind, but the bear never had any thoughts at all about that fact, and did not need to, because, fortunately for the bear, it was not responsible for designing its own teeth. ${ }^{5}$

Beresford's naturalist interpretation of Protagoras' myth seems to be based on the following three assumptions: Firstly, our natural morality consists in dispositions of the right kind. Secondly, natural morality is basically a potential for the right kind of behavior; it is waiting to be activated ('triggered') by

5 Beresford (2013, p. $15^{8}$ - italics in the original). 
cultural processes. And thirdly, Beresford claims that the myth is more an allegory for the historical origins of humanity and civilization than for the actual state of affairs described in the second part of Protagoras' speech.

Now, if Protagoras is really the author of a treatise titled On the Original Condition of Humankind (Peri tês en archê katastaseôs - D.L., IX, 55), the myth in the Protagoras can certainly be expected to contain allusions to this work. Nevertheless, this is not the function that Protagoras assigns to the myth in his speech. He definitely wants it to be an allegory for what he is going to demonstrate in the later part of his speech $(320 \mathrm{c})$. One problem with Beresford's reading is, therefore, that taking the myth to be an allegory for the original human condition unbalances its announced symmetry with the logos. If Zeus' gifts stand for our natural moral instincts, which are to be 'triggered' by a cultural intervention (so as to enable us to survive), then what is the mythical counterpart of the polis and the universal education it is said to be providing in the logos? What is the mythical equivalent of the triggering mechanism? There seems to be a missing mythical element in Beresford's interpretation. Narcy's analyses of the symmetry between the myth and the logos therefore seem to be stronger than Beresford's. For Narcy, Zeus' intervention stands for the active and continuous education the polis provides to its citizens. ${ }^{6}$

A mere problem of symmetry would not be worth mentioning. Yet this particular problem of symmetry indicates that, in Beresford's interpretation, moral activity is being sought at the wrong time: according to the myth, it would seem that human beings are morally active long before Zeus' intervention. I shall further elaborate this point later on in the paper.

Another problem with Beresford's interpretation is that Zeus seems to want the distribution of his gifts to be imbued with the universality of a command, rather than with the universality of a natural endowment. Zeus seriously considers the possibility that there might be individuals who choose not to comply with the code of his gifts (322d). Therefore, compliance with dikê and aidôs seems not to be a natural endowment, which binds each member of the species more or less equally and spontaneously, but rather a command from Zeus, which human beings had better not refuse. Those who do so will be viewed as social pests and subjected to the ultimate punishment. Zeus' gifts are thus

6 According to Claude Calame (2012, p. 137), the pragmatic effect of Protagoras' story consists in accounting for and legitimizing the present. Cynthia Farrar also thinks that 'Protagoras' story is not a naturalistic account of the rise of human society. Protagoras was interested not in how the world came to be, but in how it was. His account of the development of human society is analytic, not genetic.' (1988, p. 88). 
not intended to be universal natural endowments, ${ }^{7}$ which possess a value that could never be figured out by humans. ${ }^{8}$ On the contrary, human beings are supposed to appreciate this value.

This last point shows that Beresford's second assumption, namely that natural morality is basically a potential for the right kind of behavior, is also problematic. Human morality is not polarized as 'Either virtue or no morality! Beresford's second assumption leads him to identify 'morality' with 'being virtuous. ${ }^{9}$ However, the possibility that some individuals might fail to comply with Zeus' code suggests that in its potential form, morality does not necessarily consists in the 'right' kinds of dispositions. Consequently, active or 'triggered' morality does not necessarily consist in virtuous activity. Failing to comply with Zeus' code (and thus behaving inhumanely) remains an option for human beings. Even if we accept that human beings naturally possess the potential for the right kind of behaviour, the fact that certain individuals do not respond to the 'triggering' mechanism (education) does not render them amoral or morally inactive. ${ }^{10}$ This indicates that our natural morality does not merely consist in dispositions of the kind encoded by Zeus, and that there is hence a need for education and punishment. This is exactly the point that Protagoras is trying to make in his speech, against Socrates' claim that virtue cannot be taught.

Finally, Beresford's analyses commit him to a circularity not dissimilar to that found in the contractualist reading. If the poleis cannot exist without active virtue, and education is the necessary precondition for the emergence

$7 \quad$ Pace C. C. W. Taylor (1976, p. 88) who finds it likely that at 323a2-3, 'Protagoras fails to distinguish between the propositions (a) civilized life requires that everyone be required to be good (i.e. be subject to penalties if he fails etc.), and (b) civilized life requires that everyone be good. (a) is, arguably true, (b) obviously false. If that is so, then Protagoras will have failed to distinguish a universal normative requirement from a universal factual one.' See also Michael Nill's (1985, p. 9) suggestions to reconcile this seeming inconsistency in Protagoras' views.

8 For a similar interpretation, see also Bernd Manuwald (2013, p. 175).

9 A natural potential for the right kind of moral behavior implies an innate knowledge of the good and the bad as such. However, this view would be inconsistent with Protagorean relativism in ethics. For an interesting discussion of this question, see Eric Brown (2009). I discuss Protagorean views in the Theaetetus below.

10 In the post-Grand Speech discussion on the unity of virtues, at 329e and 349d, Protagoras considers the possibility that one can have the virtue of courage but not that of justice. This supports my point that his story does not mean Zeus' gifts to be universal natural endowments. On this point see also Nill (1985, pp. 8 - 9). 
of true and complete virtue, then neither true virtue nor the poleis can ever emerge. This perspective commits Beresford to the same position regarding the question of political existence as that taken by the contractualist. Although he makes no explicit statement of this point, the logic of his analyses makes political existence into an artifact. From his perspective, political activity would be impossible for human beings prior to the triggering of their innate normative dispositions. This results in another circularity: it takes a polis for humans to be political, and to thereby gain the capacity to found a polis.

\section{An Alternative Naturalist Reading of the Myth}

I believe that the Protagoras myth depends on naturalistic assumptions about both morality and political existence, but that they are of a different kind than Beresford suggests."1 Beresford seeks human moral activity at the wrong time because, according to the myth, human beings are morally and politically active long before Zeus' gifts. Translated into the language of the logos, Protagoras assumes that human beings are morally and politically active prior to the existence of any polis. One's moral and political existence would thus not depend upon the polis. I take this last point to be the principal anthropological assumption upon which Protagoras' account (his logos) of the present political state in Athens rests.

In the myth, almost none of the features traditionally considered to be exclusively human figures among the gifts from the gods. Reason, language and the perception of the good and the bad (the just and the unjust) are not given by any god. Language was developed by human beings after Prometheus gave them fire. By contrast, the capacity for reason is assumed to be present in humans even before Epimetheus' clumsy distribution of natural faculties: 'Epimetheus, not being altogether wise, didn't notice that he had used up all the powers on the non-rational creatures; so last of all he was left with human kind, quite unprovided for' (321c). ${ }^{12}$ The human race is unequipped except for its reason, and the difference between the reasoning and the unreasoning animals thus predates Epimetheus' work.

11 The naturalist views that I attribute to Protagoras do not necessarily belong to the historical figure himself. I rather take them to belong to the Protagoras represented by Plato in his eponymous dialogue.

Translation by C.C.W. Taylor (1976). 
Prometheus' theft, from Hephaestos and Athena, of fire and practical wisdom in order to give them to human beings, presupposed that humans were already capable, not only of receiving and understanding this technical knowledge, but also of actively using it for survival. The fact that human beings survived because they could use their reason technikôs proves that they were capable of using it correctly, at least with respect to survival. Prior to Prometheus' gifts, human beings therefore already had the nature required to become wise in the practical arts. What Prometheus gave to the human race was not reason as such, but rather a particular virtue of it. His gift made human beings capable of using technikôs their pre-existing natural capacity for reason. ${ }^{13}$

Zeus' gifts can be seen in a similar light. Protagoras says that 'since man shared in a divine gift, he was the only creature to worship the gods, with whom they had a kind of kinship, and erected altars and sacred images of the gods' (322a). ${ }^{14}$ It follows that human beings were religious before Zeus' intervention. However, this chronology of religion also indicates that, before they received dikê and aidôs from Zeus' hands, human beings were already capable of discerning the gods' apportionment, recognizing that the gods deserved respect and that humans owed respect to the gods in return for their enjoyment of divine gifts. Human beings, therefore, already possessed some sense of fairness, and were already capable of correctly discerning the just from the unjust (at least in the domain of religious affairs).

Moreover, it is said that human beings failed in their first attempts to found cities in order to survive animal attacks, because 'they wronged each other

13 One might question the likelihood of the thesis that the human capacity for reason is presupposed in the myth, and object that Protagoras does not really need to make an assumption about what enables humans to gain the arts other than their own doing: anything humans become in the myth, they become by their own effort. (I owe this observation to Ronald Polansky.) The problem with this objection is that to make sense of it we need to presuppose reason. The content of the effort that humans exhibit in order to overcome their problems of survival and the solutions they figure out cannot be explained without reference to one or another form of rationality. The myth is designed to construe the current human condition and "reason" is presupposed so that the story will make better sense. Besides, in his Prometheus Bound (440-445), [Pseudo-] Aeschylus too takes the capacity for reason as a given in humans. What his Prometheus does is help humans "achieve" their already-present rational capacities. I suspect that taking reason as a given element of the human nature is a traditional motif in the Prometheus stories.

Taylor's (1976) translation modified. 
(êdikoun allêlous)' (322b). ${ }^{15}$ Humans' refusing to band together because of the wrongs they suffered from each other indicates that they did indeed already possess a certain sense of justice. Even before they receive the virtue of justice (dikaiosunê), human beings perceive what is good and what is bad for themselves. They make a judgment (whether correct or not) and form an opinion (whether correct or not) regarding what they deserve, and they apparently expect some respect and temperance (aidôs or sophrosunê) from the others. Human beings hence always have an opinion about questions of justice, and in some cases (as that of the gods) they make correct judgements. As with Prometheus' gift of wisdom in practical sciences, what Zeus gave to the human beings is not the sense of justice as such but rather the virtue for it. Prior to Zeus' gifts, human beings already possessed a natural perceptiveness to questions of justice. Zeus granted them the virtues most intimately related to questions of justice, thus enabling them to resolve the fundamental problems that they faced whenever they tried to band together.

\section{Protagoras' Political Naturalism}

This brings me to my point about Protagoras' political naturalism. According to the myth, human beings were politically active before their reception of political virtues. Although they failed several times, they repeatedly attempted to found cities and unite in a communal enterprise. It follows that before they become capable of founding and safely governing their cities, human beings already knew how to act politically; they just did not know how to do it technikôs, for this requires technê politikê, which is precisely what Protagoras claims to be teaching. Besides, Hermes' question (322c) attests to the fact that there already existed a certain division of labor before Zeus' intervention, i.e., before the foundation of the poleis. Therefore, political existence in the myth precedes political organization. As political organization can only be the work of a political being, this makes perfect sense. This interpretation avoids the circularity of both contractualism and Beresford's naturalism.

Although I do not claim that the myth and the logos are intended to prove the naturalness of political life for human beings, I do believe that both are based on this assumption. Zeus' enterprise is clearly based on it. Firstly, Zeus could have come up with an altogether different solution. He could have said: 'These human beings cannot succeed in political life; let's give them a different

15 Taylor (1976) translates: 'They treated each other with injustice' (italics added). 
mode of life, one in which they can get along, a simpler one!' But he did not. His solution to the problems of humanity presupposes, rather than creates, our political existence. ${ }^{16}$ Contrary to the contractualist interpretation, human beings do not become political through their education in social and political virtues. As political animals, they require such an education, and Zeus responds to that need. Zeus' gifts make sense only insofar as human beings are political animals, who experience political problems that require for their solution the gifts of dikê and aidôs. ${ }^{17}$

Secondly, in the myth, the survival of non-human animal species is guaranteed by securing the survival of the individuals within that species. However, individuals who do not comply with Zeus' code are not condemned to extinction in a process of natural selection as a result of their natural deficiencies. Rather, they are subject to punishment in accordance with an established code, which can be transgressed since it is not a law of nature. After all, the section in Zeus' command concerning transgressors does not state: 'Let their race slowly become extinct, one by one and in misery! These individuals are considered to be a pestilence, not to themselves, but to society. Although Zeus wants his command to be universally binding, the qualities that the complying individuals will acquire are not meant to enable them to survive individually. Such qualities guarantee individual survival only through the survival of the society to which the individual belongs. These considerations support

16 For a similar line of argument see Nussbaum (2001, p. 102-103). Mauro Bonazzi (2012) defends a version of this view. Although I don't share his idea that according to Protagoras political existence for human beings consists in the possession and realization of aidôs and dikê Mauro Bonazzi's interpretation of Protagoras' view on the naturalness of political existence is worth mentioning here. Bonazzi thinks that Protagoras' aim in the myth is not to give a history of the development of human civilization. His aim is rather to circumscribe some anthropological facts about human beings. Accordingly, the myth has to be divided into two parts as before and after Zeus' intervention. For Bonazzi, the first part of the myth is intended to show, in a counterfactual way, what human beings are: they are political beings, and without a well-established political order, it is impossible for them to exist. Read this way, the myth intimates Protagoras' basic assumption about the priority of political existence for human beings. According to Bonazzi, 'la dimensione politica non è una conquista posteriore che conclude il cammino dell'umanità, ma è la condizione di possibilità della vita umana, degli uomini in quanto uomini.' (2012, p. 47).

17 Mario Vegetti (2004) shares a similar view on this point. According to him, the myth of Protagoras takes pleonexia and adikia as anthropological constants, which are not completely irrecoverable. According to him, both parts of Protagoras' speech (that is, the myth and the logos) underlines the need to control these two vices by law and education, in order to promote the natural propensity of man for cooperation in the polis. 
the conclusion that Zeus' actions presuppose the political nature of human beings.

\section{Protagoras in Other Dialogues}

The foregoing interpretation gives a coherent picture of Protagoras as he is represented in Plato's works. In the Theaetetus, Socrates attributes to Protagoras the idea that a wise politician replaces pernicious social conventions with beneficial ones, by making them appear just to the city (166e-167d). Wisdom in politics thus consists in promulgating laws that change the life of a city and its citizens for the better. This idea supposes that the search for what is beneficial and advantageous for human life requires some knowledge of what is better for humans. The example of sick plants and the gardener, at $167 \mathrm{~b}-\mathrm{c}$, suggests that what is meant by 'wisdom' here is some knowledge of an objective truth about what is advantageous to an organism..$^{18}$ Therefore, according to the Protagoras of the Theaetetus, although the content of law and morality diverges from polis to polis by convention, their existence targets a natural good, namely, a better state of being. For Protagoras, the fact that there is no necessary objective relation between what is just and what is beneficial for human beings calls for wisdom in the domain of politics: political wisdom aims at a 'wholesome' adjustment between these two. People make different judgements about what is just; and it takes education, virtue, and political action to turn that which promotes human well-being into law.

The thesis attributed to Protagoras in the Theaetetus is, therefore, in conformity with the assumptions of the myth. In the latter, humans are represented as having a certain natural sense of justice, without, however, being naturally capable of using it virtuously. Virtue in justice requires education. In the Theaetetus, as one consequence of his relativist position regarding justice, Protagoras is represented as stating that 'for each person and each city, things are what they seem to them to be' (168b). This is supposed to mean that each person and each city does have a judgement, i.e. a judgement of some sort, about justice; but being wise about that judgment is something different and requires an eye for what is useful and beneficial.

Besides Theaetetus, it is commonplace among scholars to consider the social contract theory formulated by Glaucon at Republic II $(358 \mathrm{e}-36 \mathrm{~d})$ as a reference to Protagoras. This is a hasty judgment and also inaccurate, because this

18 This is how Kerferd (1949) understands Protagoras' idea that an expert improves his subject. 
theory has a conspicuous Calliclean aspect that Protagoras' naturalism does not possess. The contract theory as it is construed by Glaucon is established not only on the principle that suffering injustice is bad but also on the idea that doing injustice is naturally good ( $358 \mathrm{e} 3$ ). The natural goodness of doing injustice is, in fact, the substance of the story about the ancestor of Gyges of Lydia. In the social contract account of morality as propounded by Glaucon, people establish a norm of justice despite their belief in the natural goodness of doing injustice. This aspect is completely alien to Protagoras' approach in all interpretations of it.

Plato seems to have a more or less well-framed picture of Protagoras' ethical and political naturalism, which allows him to distinguish it from other theories current in the same period. This picture is, however, in conflict with both Beresford's and Narcy's interpretations of Protagoras. In Plato, the Protagorean assumptions about the origins of morally right behavior do not refer it to human nature. Just like Zeus' 'moral intervention' with an eye to human survival in the Protagoras, the Protagoras of the Theaetetus also assumes that morally right dispositions and behaviors vis-à-vis justice are the ones which benefit human nature. But people may fail (and do ordinarily fail) to discern them (this was also Zeus' diagnosis about the post-Promethean humanity). They need to be educated and led into them. Being wise and being in a good state vis-à-vis justice is not a question of "triggering" an already existing natural disposition for just behavior. The right disposition about justice is to be acquired. However, this last point does not support Narcy's contractualist interpretation either because, in this Protagorean picture, education in morally right behavior does not consist in turning amoral beings into moral ones. Human morality as such is not a social invention, only morally right behavior is.

\section{Conclusion}

Contrary to Beresford's interpretation, Zeus' gifts do not stand for anything natural. They do, however, undoubtedly assume something natural i.e., the naturalness of human political existence and morality. Zeus' gifts make better sense on this reading: If humans were not moral and political animals, problems between neighbors would not necessitate an ethical code for social behavior as their best solution.

However, Protagoras' position does not exclude the idea of a social contract altogether. He seems to simultaneously endorse both a naturalist and a contractualist position in the sense that his contractualism is based on certain naturalist assumptions. According to Protagoras, humans are naturally perceptive 
about questions of justice and hence have a natural tendency to make judgements about justice - which does not mean that they always make virtuous judgements. This is why Zeus establishes a moral code for social behavior. If we were to translate this claim into the language of Protagoras' logos, we could say that humans figured out the value of political virtues and co-operation for themselves, and developed norms and laws to this end..$^{19}$ If they appreciate the value of the divine gift secured by Prometheus, they will also appreciate the value of a moral and social code that promotes their survival.

As sketched here, Protagoras can be considered a precursor of Aristotle's naturalism, according to which humans are political animals by nature. Like Protagoras, Aristotle also assumes that humans possess a perception of the just and the unjust. ${ }^{20}$ However, one crucial difference remains between the two thinkers: unlike Aristotle, Protagoras' naturalism is not eudaemonist. ${ }^{21} \mathrm{His}$ stance on the naturalness of political and moral life for human beings does not take the form of an ethical reflection upon the telos of human life as such. Not only in comparison to Callicles, but in comparison to Aristotle too, Protagoras' naturalism does not have any determinate normative content. If it is true, as Gregory Vlastos has suggested, that eudaemonism ${ }^{22}$ becomes foundational for virtually everyone after Socrates, then Protagorean naturalism is a pre-Socratic position in this specific sense too.

\section{Bibliography}

Beresford, A. (2013), 'Fangs, Feathers \& Fairness: Protagoras on the Origins of Right and Wrong', in: J.M.V. Ophuijsen, M.V. Raalte and P.Stork (eds.), Protagoras of Abdera: The Man, His Measure, Leiden and Boston: Brill, pp. 139-162.

Bonazzi, M. (2012), "Il mito di Prometeo nel Protagora: una variazione sul tema delle origini", in F. Calabi adn S. Gastaldi (eds.), Immagini delle origini. La nascita della cvivilità e della cultura nel penserio antico, Sankt Augustin, Academia Verlag, pp. 41-57.

Brown, E. (2009), 'Plato's Rejection of Protagorean Ethics', in (symposium): Plato and Naturalism, Eastern Division Meeting of the American Philosophical Association, December.

19 This reading is considered by Beresford (2013, p. 149) but he dismisses it without any substantial argument and he rejects this interpretation later, on p. 158 (quoted above on p. 48).

20 For both theses, see Aristotle's Politics, I. 2, 1253a3-19.

21 I thank Ronald Polansky for bringing this point to my attention.

22 According to Vlastos (1991, p. 203), "eudaemonism" is the idea that happiness is desired by all human beings as the ultimate end of all their rational actions. 
Calame, C. (2012), 'The Pragmatics of 'Myth' in Plato's Dialogues: The Story of Prometheus in the Protagoras', in: C. Collobert, P. Destrée and F.J. Gonzalez (eds.), Plato and Myth: Studies on the Use and Status of Platonic Myths, Leiden and Boston: Brill, pp. 128-143.

Collobert, C. and Destrée P. and Gonzalez, F.J. (2012), 'Plato and Myth. Studies on the Use and Status of Platonic Myths', Leiden and Boston: Brill.

Farrar, C. (1988), The Origins of Democratic Thinking. The Invention of Politics in Classical Athens, Cambridge: Cambridge University Press.

Kerferd, G.B. (1949), 'Plato's Account of the Relativism of Protagoras', in: Durham University Journal 42: 20-34.

Manuwald, B. (2013), 'Protagoras' Myth in Plato's Protagoras: Fiction or Testimony?', in: Ophuijsen, J.M.V., Raalte M.V. and Stork P. (eds.), Protagoras of Abdera: The Man, His Measure, Leiden, Boston: Brill, pp. 163-177.

Narcy, M. (1990), 'Le Contrat Social: d'un Mythe moderne à l'ancienne sophistique', in: Philosophie $28: 3^{2-56 .}$

Narcy, M. (2008), 'Three Versions of the Nomos - Phusis Antithesis: Protagoras, Antiphon, Socrates', in: A. Pierris (ed.), Physis and Nomos: Power, Justice and the Agonistical Ideal of Life in High Classicism, Institute for Philosophical Research, Conference Series 4, pp. 381-400.

Nill, M. (1985), Morality and Self-interest in Protagoras, Antiphon and Democritus, Leiden: Brill.

Nussbaum, M. (2001), The Fragility of Goodness. Luck and Ethics in Greek Tragedy and Philosophy, Cambridge: Cambridge University Press.

Ophuijsen, J.M.V., Raalte M.V. and Stork P. (2013), Protagoras of Abdera: The Man, His Measure, Leiden, Boston: Brill.

Riel, G.V. (2012), 'Religion and Morality. Elements of Plato's Anthropology in the Myth of Prometheus', in: C. Collobert, P. Destrée and F.J. Gonzalez (ed.) Plato and Myth: Studies on the Use and Status of Platonic Myths, Leiden and Boston: Brill, pp. 145-164.

Taylor, C. C. W. (1976), Protagoras, Oxford: Clarendon Press.

Vegetti, M. (2004), "Protagora, autore della Repubblica? (ovvero, il 'mito' del Protagora nel suo contesto)", in G. Casertano (ed.), Il Protagora di Platone: struttura e problematiche, Napoli: Loffredo, pp. 145-158.

Vlastos, G. (1991), Socrates: Ironist and Moral Philosopher, Cambridge University Press: Cambridge. 